\title{
The Eastern Democratic Republic of Congo Recurring Conflict: Whose Conflict Transformation Responsibility?
}

\author{
${ }^{1}$ Sadiki Maeresera, ${ }^{2}$ Engelbert Abel Rugeje \& ${ }^{3}$ Knocks Zengeni \\ ${ }^{\prime}$ Institute of Strategic Research and Analysis, National Defence University's Zimbabwe \\ ${ }^{2 \& 3}$ School of International Studies, Universiti Utara Malaysia, Malaysia \\ ${ }^{1}$ Corresponding author: sadikimm@yahoo.com \\ DOI: https://doi.org/10.32890/jis2018.14.3
}

Received: 25 April 2018

Revised: 5 August 2018

Accepted: 10 November 2018

\begin{abstract}
The recurring conflict in Eastern DRC has had devastating effects on civilians, mostly in Kivus. From the beginning of January 2002 till the end of May 2017, many conflict resolution efforts have been put together by regional and international communities. However, there has not been any sustainable mechanism to resolve the conflict. The situation regarding the security of Eastern Congo continues to be volatile. This paper seeks to identify the responsible party that would help mitigate the recurring conflict in Eastern Congo. Using the three distinct categories of actors in Conflict Transformation, the paper argues that the lack of coordination among these actors who constitutes the three Track levels have affected unity of purpose and the level of commitment as far as transforming the Eastern Congo Conflict. The divergent interests among the respective actors to outmaneuver one another when it comes to agenda setting regarding respective peace initiatives on conflict, could be the rationale behind the absence of a workable formula in transforming conflict in the Eastern DRC. The paper proffer strategic policy suggestions toward a workable Conflict Transformation mechanism that equitably addresses the root causes of the conflict and fairly incorporates the relevant stakeholders in an effort to find a sustainable solution.
\end{abstract}

Keywords: Eastern Democratic Republic of Congo, Recurring conflict, Conflict Transformation Responsibility.

\section{Introduction}

The eastern DRC conflicts continue to have a devastating effect on innocent civilians, mostly in North and South Kivu. From the beginning of 2002 to the first half of 2017, there have been a plethora of efforts that were orchestrated by national, regional, and international state and non-state actors in an effort to resolve the conflict. However, there has not been any sustainable mechanisms in place. The situation concerning the security in that part of the country remains relatively volatile. This article analyses the typology of Conflict Transformation. A contextual framework is made with reference to actors who constitutes 
the Three Track levels in transforming conflict. The dynamics surrounding the eastern DRC conflicts are briefly discussed with the aim of identifying who is responsible to transform the conflict. Apart from that, it is further noted that the lack of coordination, low level of commitment and unity of purpose among actors from Track 1, 11 and 111, affected the extent to which the root causes of the conflict were addressed. The diverging interests among the respective actors who constitutes the three Tracks could also be the major reason why there was a lack of a workable formula that takes into account the interests of all the major players in the attempt to resolve the conflict in Eastern Congo and build sustainable peace. A brief discussion examines the strategic policy and scholarly recommendations toward a workable Conflict Transformation mechanism that equitably addresses the root causes of the conflict, and fairly incorporates the relevant stakeholders in an effort find a sustainable solution.

\section{Methodology}

The authors used a qualitative research design that premises on discussions with scholars, and interviews from experts with representatives from factions that are involved in the conflicts in Eastern Democratic Republic of Congo. The study was further supported by various secondary resources drawn from around the globe to discuss conflict transformation responsibility that are involved in the intractable conflicts of the Great Lakes region.

\section{The Typology of Conflict Transformation}

Conflict Transformation comprises a broad range of actors, who make use of a wide gamut of applications. These actors, shape the development of contemporary practice and can be categorised into groups; States and intergovernmental organisations; development and humanitarian organisations; international non-governmental organisations concerned with conflict prevention and transformation; and parties to the conflict and other relevant groups within the affected societies (Miall, 2004, p.12). There are also three distinct categories of actors that Conflict Transformation attempts to change. As observed by Bichsel (2009) "Conflict Transformation does not only attempt to transform relations between groups, but also between three levels of actors perceived to represent the socio-political construction of a state" (p.40). These three levels of actors are usually referred to as 'Tracks.'

Track I includes governmental and diplomatic actors with official and formal activities, who have high visibility and publicity (Reimann, 2004). When conducting peace-building activities, the top leadership can be accessed by mediation at the level of states (Track I) and by the outcome-oriented approach. Track I actors usually rely on mediation efforts and negotiations in their attempts to resolve conflicts. The various mediation efforts are through individual member states (for instance South Africa, Uganda, Angola, among others), the sub regional institutions (the SADC, the EAC, the ICGLR), the continental mechanism 
(the African Union) and a number of peace efforts by notable political personalities, such as former President Olusegun Obasanjo's involvement in the Eastern DRC. These efforts serve as examples of Track I actors in the context of the recurring conflict.

Track I level of actors, such as peace and security practitioners, states, and international organisations are comprised of the most influential people (Rugeje, 2017). Furthermore, their actions have a notable impact in influencing the conflicting parties. Track 1 level actors have a sense of responsibility due to their publicized peace intervention efforts that are prone to public scrutiny (Miall, 2004, p.12; Rugeje, 2017). Since the early 1990s to the first quarter of 2017, the UN has managed to come up with peace support mechanisms in conflict ridden areas around the globe. One of the mechanisms include the development of a model which calls for military measures such as the demobilization, disarmament and establishment of buffer zones for conflicting armed groups in any given context. In addition to military measures, there are constitutional mechanisms which have been, and continues to be applied by the UN as a primary Track 1 actors. These include the rehabilitation of war damaged infrastructure, provision of assistance in the documentation and return of refugees, and the professional training of local police in the maintenance of law and order, among others (Miall, 2004, p.12; Pfetsch and Rohloff, 2000; Rugeje, 2017). Despite such efforts by the UN as part of the Track 1 actors in transforming given conflicts, there are instances where recurrence of violent armed conflicts have taken place particularly in Cambodia, Ivory Coast, Central Africa Republic, South Sudan, Burundi, Lesotho, Mozambique, and the Eastern DRC.

As part of Track 1 actors, the international community and the UN has made significant efforts to prevent violent conflicts. The same actors have played significant roles even though there are changes in the context and structures of conflicts over the years. A notable example was the effort made by the Organisation for Security and Cooperation in Europe (OSCE)'s High Commissioner on National Minorities with the support of the European Union (EU) and Scandinavian governments in forestalling the Estonian ethnic conflict (Cochrane and Seamus 2002; Rugeje, 2007). The same Track 1 actors introduced the electoral system that resulted in cross-ethnic voting. This led to a shift from ethnic politics, to politics of economic and regional interest groups. There was an inclusion of Non-Estonian politicians in the lists within the Estonian parties in order to cater for a relatively fair representation of their interests, thus promoting ethnic accommodation (Rugeje, 2017).

The military equally plays a critical but limited role in supporting Track I efforts. Military contingents and police forces such as the UN and the North Atlantic Treaty Organisation (NATO) peace support forces are normally employed to end hostilities and prevent resumption of armed conflicts. Maintaining a ceasefire (including coercive means) provides the opportunity for dialogue between governments and politicians to transform potentially violent conflicts, into peaceful non-violent processes of social and political change (Boehlke 2009, p.15). In the context of the Eastern Congo conflict, there is need to fortify the role 
of military (that is, the local Congolese Armed Forces -FARDM, the Force Intervention Brigade and MONUSCO peacekeeping troops) in executing respective peace support roles.

Track II focuses on the 'middle-level' or 'middle range' leadership. The Track 11 leadership includes those who occupy respectable positions in the socio-economic formal sectors such as health and education, among others. Transitional councils in mild post conflict environments is a good example. Paffenholz (2009, p.5) observes that the Track 11 or Mid-level leadership are involved in processes through resolution-oriented approaches that includes problem-solving workshops and peace-commissions, with the help of partial insiders who are usually prominent individuals in society. The activities of Track II diplomats include the organisation of problem-solving workshops, seminars and conferences, provision of mediation courses, and acting as mediators in facilitating dialogue between antagonistic communities including arranging behind the scenes diplomatic dialogue between personalities from rivalry political parties (Havermans, 1999, p. 223). With regards to the Eastern DRC recurring conflict, there is a need to continuously make scholarly and strategic policy efforts in identifying Track 11 initiatives that have been taken and those that are being planned to resolve the conflict. By pursuing scholarly and policy endeavors, Track 11 actors in the Eastern Congo conflict must make sufficient arrangements and preparations to resolve the warring armed and non-armed conflicting parties. During the preliminary stage, sufficient information must be collected and analysed to garner an understanding on the dynamics of the conflict and the parties involved. Therefore, in Track 11, there must be prior coordinated arrangements for meetings between representatives of rival armed groups. Such efforts must be treated with extreme caution so that the proceedings do not degenerate into a verbal showdowns that would lead to further complexities in resolving the conflict.

The development and humanitarian agencies constitutes Track 11 level of actors. Miall (2004, p.13) notes that these agencies have the responsibility of assisting in the reconstruction activities in war torn societies. They engage in development programmes that are aimed at assisting nations recovering from armed conflicts. A notable example of how development and humanitarian agencies play a crucial conflict transformation role, is the utilisation of development aid as an instrument for mitigating conflict. Development programmes such as those meant to assist in the reintegration and rehabilitation of child soldiers do have an impact as far as transforming a conflict is concerned. However, development aid can have negative consequences on peace efforts if not managed well (Ramsbotham \& Woodhouse, 1996, p.56; Rugeje, 2017). Moreover, if the aid is captured by armed groups, it could potentially be used to sustain their logistical capacities and thereby instigate further conflict.

Whilst development agencies act as supporting entities, which principally encourage the work of others, most of the Conflict Transformation work is expected to be done by the NGOs. NGO practitioners advocate a sustained level of engagement over a longer period of time and seek an in-depth understanding of the roots of conflict while working closely with the grassroots both within and outside the conflicting parties (Lederach, 1997, p.15; Rugeje, 2017). In addition, NGOs play multifarious roles in the peace-building endeavors 
that includes their facilitation of dialogue among conflicting parties, logistical and technical sustenance of local, national and regional as well as international conferences and workshops on paths towards peace, identification and engagement of opportunities for peace-building, and the development of relationship building and institution building over the long term (Rugeje, 2017). To accomplish their respective peace building roles, the Track 11 actors employ certain tools, instruments and methods which includes supporting and sustaining local groups and social movements, building peace constituencies, strengthening capacity, empowering key actors, organisational development, and networking and training (Miall, 2004, p.15; Rugeje, 2017).

As noted by Lederach (1997, p. 38), Track III refers to the "grassroots" leadership which represent the population at large. The Track III level of actors represents the majority of the local population (Paffenholz, 2009, p.5). Their representations are made through a wide range of peace-building approaches that comprises of local peace commissions, community dialogue projects or trauma healing (Rugeje, 2017). Local actors have the supreme mandate and a superlative opportunity for transforming their own conflicts. At times, there are third parties who emerge out of conflicting parties. These usually promote opportunities to open avenues for dialogue and political engagement (Fitzduff 1999, p. 42). In some political parties, there are instances whereby certain groups can bring about an actor transformation, such as the shift towards political forms of struggle (Rugeje, 2017). Civil society actors and local NGOs often carry on enormous influence on building bridges between political parties and local communities to address the problems of historical memories and reconciliation (Miall 2004, p.15). The impact of this peace building endeavour on the macro level of the conflict is hard to evaluate. However, the personal and group transformations that it will achieve are of importance. Hence, to answer the question regarding whose Conflict Transformation Responsibility in the Eastern DR Congo recurring conflict, this paper will critically analyse the peace support problematique using mutually elaborated connection while incorporating productive amalgamation of the levels by fostering dialogue and cooperation between actors described in Tracks 1, 11 and 111. Furthermore, there is a greater need for multilevel participation and dialogue between the Tracks (Reimann 2004, p.14; Mitchell 2009, p. 9). It is prudent to briefly discuss the dynamics surrounding the Eastern DRC recurring conflict.

\section{The Eastern DRC Recurring Conflict's Dynamics}

The armed conflict in the Eastern DRC has been a cyclic phenomenon. Since 2002 to the first quarter of 2017, there has been violent armed activities by a number of different groups. The militias operating in Eastern Congo, includes the M23 armed rebel group and its allied militias, Mai Mai Sheka and other collaborative groups, Mai Mai Morgan and its allies, Mouvement d'Action pour le Changement, Allied Democratic Forces, Coalition des Groupes Armés de l'Ituri and the Forces de Défense Nationale (Enough Project, n.d). For almost two decades, some of these armed militias have conducted violent and inhuman acts 
of aggression towards the Congolese civilians. There have been reports of mass killings of unarmed civilians, sexual abuse of women and underage girls, forced recruitment of child soldiers into the various armed groups operating in the eastern part of the country, and the displacement of more than half a million people. Despite a plethora of political, diplomatic, and military mechanisms that have been placed by the relevant stakeholders in assisting the country on its path to ending the recurring conflict, there has not been lasting peace in the DRC in general, particularly in the eastern part of the country.

The Eastern DRC recurring conflict has generally been revolving around the armed activities by the militias groups in North and South Kivus. These militias have been engaged in armed attacks with the Congolese Armed Forces (FARC) which are deployed to Eastern Congo with assistance from the United Nations peacekeeping troops, that is made up of Congolese civilian personnel from respective government institutions. There has been academic and strategic policy questions regarding the powers behind formation of the military and to some extent, the political structures of these armed militias operating in Eastern Congo as well as the provisions of logistical and technical assistance that sustain their insurgency efforts. There are also conspiracies concerning accusations and counter accusations on where the support for pro and anti-government armed groups emanated from. Perera and Beswick (2013) suggests that the three major players at the centre of the political and military conspiracies who offered support to the rebel militias have been the government of the DRC itself and the governments of Rwanda and Uganda.

Dizolele (2004) observes that the DRC Congolese government has been blamed by the governments of Rwanda and Uganda for the lack of relative capacity to have full control of the politics and security of Eastern Congo. Dizolele (2004) further argues that the inability of Kinshasa to sustain guaranteed peace and security in Eastern DRC has been of great concern to both Kigali and Kampala. The lack of control of the eastern part of the country by the DRC government has arguably been a key causal factor that has enabled armed rebel militias, notably the Forces for the Democratic Liberation of Rwanda (Interahamwe) and the Lord's Resistance Army, to create military bases in North and South Kivu (Dizolele 2004). Furthermore, Dizolele (2004) views that such a scenario can leave the governments of Rwanda and Uganda to justify their believe that "a less DRC government controlled Eastern Congo, specifically North and South Kivus, will always and continuously be used as launching pads for military attacks on Uganda and Rwanda".

Whilst there have been scholarly and policy views against the DRC, they have mostly been allegations by Rwanda and Uganda. The governments of Rwanda and Uganda have been blamed for the political formation and military structuring of rebel militias that fighting against the Congolese government. These militia groups include the National Congress for the Defence of the Congolese and the M23 rebels. These groups have been launching military attacks against troops of the Congolese government. Before counter-offensive operations by the International Monitoring Force which led to militias withdrawing into Uganda and in some parts of Rwanda, these rebel groups have reportedly been carrying out various acts 
of sabotage, mass killing, torture of innocent civilians, rape, and forced recruitment of child soldiers. Most of these rebel groups' successful military operations prior to the deployment of the International Monitoring Force were dependent on the alleged provisions from political support, and military logistical and technical sustenance from Rwanda. However, allegations against the governments of Rwanda and Uganda have been criticized by three anonymous Great Lakes regional security analysts. They observed that the effect for the defections of Congolese troops to rebel militias cannot primarily be a result of strategic intelligence crafted by Rwanda and Uganda. The defections experienced was a result of a disorganized security sector, particularly the military service by the Congolese government. The same analysts had corroborating views on their criticism against of the Congolese government. They blame the DRC government for not being able to train and retrain its military effectively, and efficiently equip and administer the troops of the Congolese Armed Forces. Subsequently, this led to their inability to execute their constitutional obligation of defending the DRC's territorial integrity ${ }^{1}$.

The political dynamics and military developments in Eastern Congo has had devastating effects on the Congolese civilian population. Whilst the DRC government has been struggling to restore peace and security in the eastern part of the country, there has been less progress made in the attainment of durable peace and a sustainable formula in dealing with the recurring conflict. It then leaves the political and security analysts with the daunting question: whose responsibility is it to transform the Eastern DRC recurring armed conflict?

\section{Whose Conflict Transformation Responsibility?}

With reference to the Eastern DRC recurring conflict, the UN (together with respective state actors and regional organisations) arguably falls into the Track 1 level of actors- the level whereby actors play a significant role in transforming the conflict. As an international body with the mandate to preserve global peace and security, the UN must work together (and it is expected to continue doing so) with relevant state actors, regional organisations, diplomatic practitioners, complemented by military support from local, regional and international forces.

As part of its international peace and security obligation, the UN has been involved in diplomatic and political initiatives that were created to resolve the conflict. International warrants of arrest by the International Criminal Court (ICC) has been issued against the leadership of armed militias operating in the Eastern DRC and sanctions have been imposed for crimes against humanity (Matsiko 2013; Maeresera \& Zengeni, 2016). The UN political efforts have since been augmented by military peace and support efforts from troops constituting the United Nations Observer Mission in Congo (MONUSCO) and the United Nations Force Intervention Brigade (UN FIB) (Rugeje \& Maeresera, 2016). With

\footnotetext{
The two authors are indebted to the viewpoints from separate discussions with relevant analysts on 25 May 2013 by Dr Sadiki Maeresera and 17 June 2016 by Lt Gen (Dr) Engelbert Abel Rugeje.
} 
the complementary efforts of the UN FIB, the MONUSCO has managed to progress in its military efforts to stabilize the violent armed conflict in the Eastern DRC (Menodji 2013; Maeresera \& Zengeni). To date, MONUSCO has significantly managed to facilitate dialogue between the armed and non-armed conflicting parties, despite the challenges encountered as a result of some political and strategic misunderstandings between the UN Mission and the DRC government. Relative lack of cooperation between the two had centered on the DDRRR program. The DRC government was blamed by MONUSCO for not cooperating on the aspects of DDRRR. The UN Mission accused Kinshasa for providing covert assistance to negative forces such as the FDLR and the Mayi Mayi. The Congolese government was also accused of engaging in collaborative military operations with the same negative forces. The allegations have continuously been denied by Kinshasa (Menodji 2013; Maeresera \& Zengeni, 2016).

At the Track 1 level, complementary efforts from state actors have been in the form of bilateral political initiatives by the governments of the DRC and the respective neighbouring countries (notably Rwanda and Uganda) whose national security interests continue to be affected by the Eastern Congo recurring conflict. The governments of DRC, Rwanda and Uganda have been engaged in Joint Permanent Commissions (JPCs) on Politics, Defence and Security (Maeresera \& Zengeni, 2016). The JPCs were taking place bilaterally in the beginning, alternating between the governments of the DRC and Rwanda and between the DRC and Uganda. Eventually, the JPCs was held at the tripartite level between the three countries (Maeresera \& Zengeni, 2016). Generally, the deliberations of the JPCs have been discussed at different levels of the Presidency, Foreign Affairs, Defence and Security ministries. The initiatives were carried out to find a lasting solution to the recurring conflict. The DRC government's bilateral political arrangements resulted in the joint military cooperation between the two neighbouring countries. The FARDC went on to conduct offensive operations with their counterparts from both Rwanda and Uganda (Maeresera \& Zengeni, 2016). The joint military operations were aimed at preventing the escalation of armed activities by negative forces operating in Eastern Congo. One such military operation was Umoja Wethu, which was conducted by the FARDC and Rwanda Defence Forces (RDF) to counter threats posed by the FDLR, CNDP, to Kigali and Kinshasa respectively (International Crisis Group 2009, pp.3-11; Maeresera \& Zengeni, 2016).

Whilst the above efforts were extensive, there has been less progress in reducing the escalation of armed hostilities in the Eastern DRC. There have reports of massive forcible recruitment of child soldiers by the armed militia groups, rape, and looting that has caused insecurity among the civilian population. The joint bilateral political and military cooperation between Kinshasa and the respective neighbouring countries achieve less of what was expected with regards to facilitating the attainment of sustainable peace and security in the Eastern DRC and beyond. The various militia groups continue to carry out armed activities mostly against innocent civilians. The same rebel groups operating in Eastern Congo continued to be a national security threat to the governments of DRC, Rwanda and Uganda. The DDR programme has been an elusive peace process (International Crisis Group 2009, p.13-16). 
Under such circumstances, the security situation in the Eastern DRC remains complex and the possibility of a full-scale armed conflict cannot be ruled out.

The regional organisations that are operating under the Track 1 level of actors includes the African Union (AU) and its sub regional arrangements such as the East African Community (and more or less through the International Conference of the Great Lakes Region-ICGLR) and the Southern African Development Community (SADC). The Eastern Congo recurring conflict has been and continues to be on the agenda of AU Heads of State Summits and the Peace and Security meetings (Maeresera \& Zengeni, 2016). The continental body went a step further and took the initiative of appointing the former Nigerian President Olusegun Obasanjo as the AU Special Envoy to Eastern DRC. Such a peace effort was aimed at trying to bring the various armed groups to the negotiating table (Feeleyand Thomas-Jensen 2008). As for the EAC, political efforts at resolving the conflict has been made through the facilitation and promotion of dialogue among the belligerents. There have been a number of diplomatic maneuvers by the EAC, through the ICGLR, in devising a plan for a peaceful solution to the Eastern Congo recurring conflict.

In addition to the EAC/ICGLR efforts, the SADC has also been trying to come up with various political, diplomatic and military/security initiatives at resolving the conflict in Eastern Congo and for building sustainable peace. At the SADC political and diplomatic level, the Eastern Congo conflict has been the prime consideration especially at the SADC Heads of State and Government Summits. However, like the EAC and ICGLR, the SADC has continued to encounter an array of political, diplomatic, military and security challenges from within. These challenges include, among others, negative external interference which affects attainment of commonality of regional interests for peace and security, and a less sustainable regional resource base (Baker \& Maeresera, 2009; Ngoma, 2004; Zambara, 2013).

The political, military and security hurdles so far encountered by the UN, AU, EAC/ ICGLR and SADC can be viewed through the lenses of the remarkable observation made by the President of Uganda, Yoweri Museveni at the 2012 SADC, which was convened to deliberate on how to resolve the conflicts in the sub-region, particularly the Eastern Congo recurring conflict. The Ugandan President observed that there is a need for the SADC to exercise cautious when dealing with the Eastern Congo conflict (Zambara, 2013). President Museveni argued that any of the SADC efforts at resolving the Eastern Congo recurring conflict and achieving durable peace should consider two critical issues. The first, is that the conflict and instability in Congo has affected the Congolese people and their neighbouring countries; and the second, is that the same conflict and instability is strictly internal (Zambara, 2013; Maeresera \& Zengeni, 2016). The observation made by the Ugandan President seemed to have summed up the generality of the nature and scope upon which created the challenges encountered by the Track 1 level of actors. Furthermore, it is imperative to discuss briefly the extent to which Track 11 and 111 level of actors that have not been significantly involved in the quest for transforming the Eastern Congo conflict. 
The Track 11 leadership includes respectable appointees in the socio-economic formal sectors such as health and education. In the context of recurring conflict in the Eastern DRC, there has not been any inclusion of Transitional councils meant to play important roles in a mild post conflict environment. Besides, it can be argued that there has been less efforts at reaching out to the Track 11 or Mid-level leadership of the DRC and its immediate stakeholders to the Eastern Congo conflict through the use of resolution-oriented approaches such as problem-solving workshops or peace-commissions with the help of prominent members from the North and South Kivus and those from across the borders. Whilst Track II diplomats have so far managed to organise problem-solving workshops, seminars, conferences, and provision of mediation courses with the specific focus on Eastern Congo, it is unfortunately, superficial. With the appointment of Olusegun Obasanjo by the AU, there has been no tangible attempts at mediating and facilitating dialogue between the Eastern DRC communities, as well as arranging behind the scenes diplomatic dialogue between personalities from rival political parties and armed militias. A number of development and humanitarian agencies who also constitute the Track 11 level of actors have been involved as part of their responsibility in providing assistance in the reconstruction activities in Eastern Congo during cessation of conflict in the region. The same actors have also been involved in development programmes to assist in the reintegration and rehabilitation of child soldiers. However, it can be deduced that role played by Track 11 level actors seemed to be insignificant. The lack of success could have been exacerbated by the relative lack of support and assistance (let alone role conflict), from the level 1 actors.

Moreover, the quagmire of transforming the conflict in the Eastern DRC revolved around the lack of significant cooperation between Track 1 and 11 level of actors. In the same vein, the primary Track 111 level of actors, which are mainly the 'grassroots' leadership of the Eastern DRC (which represent the population of Kivus), have not been incorporated or included in the result oriented peace-building approach processes. From the study conducted, it is infered that the Track 111 actors were not part of the process that included the local peace commissions, community dialogue projects or trauma healing processes in the Eastern Congo. The Track 111 actors were not given any chance to play a significant role in opening avenues for dialogue and political engagement.

With reference to the level of actors, there is a need to weigh in on the sustainability of mechanisms that would be put in place to mutually and concurrently assist each other, from governmental (state), civil (non-state) and grassroots levels in the quest for the transformation of the Eastern DRC recurring conflict.

From the foregoing, it is prudent to argue that the allotment of Conflict Transformation Responsibility in the Eastern Congo's recurring conflict be grounded on the need to build blocs on sharing responsibility for conflict resolution and sustainable peace-building. The conflict in Eastern DRC falls within the three Track level of actors' responsibility. The preservation of international, regional and national peace and security should be a shared responsibility of the Track 1 level of actors (the international community -under the UN, 
together with the AU and sub regional entities- the EAC/ICGLR, the SADC, state actors mainly the DRC and the immediate neighbouring countries of Rwanda and Uganda). This is in the consideration that the Eastern Congo conflict do pose national security threats to the entire Great Lakes region and may have spill-over implications on Africa and beyond. There is also a need for either a top down or bottom up approach (as long as it is all encompassing and collaborative). The Track 1 level should devise a workable plan for a coordinated synergy at diplomatic, political and military/security level with the inclusion of other role players (those that make up Tack 11 and 111 levels). A collaborative synergy of efforts by all key actors that constitutes the three Tracks would make a significant impact in transforming the conflict (Paffenholz \& Spurk 2006; Maeresera \& Zengeni, 2016). For such synergies to be realized, scholarly initiatives must be amplified and established to promote research through local, national, regional and international think-tanks with primary emphasis on Conflict Transformation and peace-building.

\section{Conclusion}

The recurring conflict in the Eastern DRC, has led to the insecurity and danger of innocent civilians in North and South Kivu. From 2002 to 2017, many efforts by the state and nonstate actors at the national, regional, and international levels have been less significant in resolving the conflict. The security situation in some parts of the Eastern DRC remains relatively unstable and peace is far from being achieved. In analyzing the contentious issue of whose responsibility it is to transform the conflict, a brief typology of Conflict Transformation was made and references were given to the actors who constituted the Three Track levels in transforming conflict. The dynamics surrounding the Eastern DRC conflict was discussed with the general objective of examining who among the identified actors have the responsibility to transform the conflict. It was noted that the lack of coordination, low levels of commitment, and unity of purpose among the actors from Track 1, 11 and 111 were affecting the root causes of the conflict that has been identified by these actors. The strategic policy and scholarly recommendations toward a workable Conflict Transformation mechanism to equitably address the root causes of the conflict and subsequently incorporate the relevant stakeholders in an effort find a sustainable solution to the conflict.

\section{References}

Baker, Deane-Peter, Sadiki Maeresera. (2009). SADCBRIG intervention in SADC member states: Reasons to doubt. Africa Security Review, 18 (1), 106-110.

Bichsel, C. (2009). Conflict transformation in central Asia: Irrigation disputes in the Ferghana Valley. London: Routledge.

Boehlke, T (2009) Conflict transformation by military involvement. In Lundqvist, K. (Eds.), Conflict transformation: Three lenses in one frame New Routes: A Journal of Peace Research and Action, 14 (2). 15-19. Retrieved from http://www.life-peace.org/wpcontent/uploads/2013/06/nr_2009_02.pdf 
Cochrane, F., \& Seamus, D. (2002). People power: The role of the voluntary and community sector in the New York. Cork: Cork University Press.

Enough Project. Democratic Republic of Congo. Retrieved from http:/www.enoughproject. org/conflicts/eastern_congo.

Feeley, R., \& Thomas-Jensen, C. (2008, December 11). Beyond crisis management in eastern Congo. Enough Strategy Paper. Retrieved from https://enoughproject.org/ files/easterncongo_1208.pdf

Havermans, J. (1999). Private professionals for peace in people building peace. New York: Algorn Press.

International Crisis Group (2009, July 9). Congo: A comprehensive strategy to disarm the FDLR. Africa. Report Number 151, Retrieved from: .http://www.crisisgroup. org/ /media/Files/africa/central-africa/dr-congo/151\%20Congo\%20\%20A\%20 Comprehensive\%20Strategy\%20to\%20Disarm\%20the\%20FDLR\%20-\%20 ENGLISH.pdf

Lederach, J P, (1995). Conflict transformation in protracted internal conflicts: The case for a comprehensive network. In Kumar Rupesinghe (Ed.), Conflict Transformation. New York: St Martin's Press.

Lederach, J. P. (1995). Preparing for peace. New York: Syracuse University Press.

Lederach, J. P (1997). Building peace: Sustainable reconciliation in divided societies. Washington, DC: United States Institute of Peace.

Lederach, J. P. (2000) Conflict transformation: A working definition. In Cynthia Sampson \& J. P Lederach (Eds.), From the ground up: Mennonite contributions to peacebuilding. New York: Oxford University Press.

Lederach, J. P. \& Maiese, M. (2003). Conflict transformation: Beyond intractability. New York: Good Books.

Maeresera, S., \& Zengeni, K. T. (2016). Recurring armed conflict in the Eastern Democratic Republic of Congo: An insight into the SADC intervention problematique. Paper presented to the $6^{\text {th }}$ International Conference on International Studies. Kuala Lumpur, 20-21 August.

Matsiko, H. (2013, January 20). Congo-Kinshasa: M23 rebels fear war over sanctions. Retrieved from http://www.independent.co.ug/news/regional-news/7268-m23-congorebels-fear-war-over-un-sanctions

Menondji, M. H. A. (2013, February 4). Problematic peacekeeping in the DRC: From MONUC to MONUSCO; Why have large-scale international efforts to end the violence in the DRC failed again and again? Retrieved from: http://thinkafricapress. com/drc/problematic-peacekeeping-drc-monuc-monusco

Miall, H. (2004) Transformation: A multi-dimensional task. Berghof Foundation.

Mitchell, C. (2009). Beyond resolution: What does conflict transformation actually transform? Peace and Conflict Studies, 9(1), 1-23.

Mvemba, P. D. (2004, May 10). The UN in Congo: The failure of a peacekeeping mission. The New York Times. Retrieved from http://www.worldsecuritynetwork.com/UNOther/mvemba-dizolele/The-UN-in-Congo-The- failure-of-a-peacekeeping-mission 
Ngoma, N. (2004). Hawks, doves and penguins: A critical review of SADC military intervention in the DRC. Institute of Security Studies Occasional Paper 88, Institute of Security Studies, Pretoria. Retrieved from: http://www.issafrica.org/index. php?link_id=3\&slink_id=519\&link_type=12\&slink_type=12\&tmpl_id=3.

Paffenholz, T. (2009). Understanding peacebuilding theory: Management, Resolution and Transformation. In Lundqvist, K. (Eds.), Conflict Transformation: Three Lenses in One Frame - New Routes: A Journal of Peace Research and Action, 14(2). 3- 6. Retrieved from http://www.life-peace.org/wp-content/uploads/2013/06/nr_2009_02. pdf

Paffenholz, T., \& Spurk, C. (2006). Civil society, civil engagement, and peacebuilding: Social Development Papers. Conflict Prevention and Reconciliation Paper, 36. 2327. Retrieved from http://siteresources.worldbank.org/INTCPR/Resources/WP36_ web.pdf

Perera, S., \& Beswick, D. (2013, June 27-29). Security complexes and complexities in the eastern DRC. Paper presented at the $5^{\text {th }}$ European Conference on African Studies: African Dynamics in a multipolar world, Lisbon, Retrieved from http://www. nomadit.co.uk/ecas/ecas2013/panels.php5?PanelID=2105

Pfetsch, F., \& Rohloff, C. (2000). National and international conflicts 1945-1995. London: Routledge.

Ramsbotham, O., \& Woodhouse, T. (1996). Contemporary conflict resolution. Great Britain: Polity Press.

Reimann, C. (2004). Conflict resolution and peacebuilding. Bradford: Centre for Conflict Resolution.

Rugeje, E. A. (2017). Recurring conflict in the Eastern Democratic Republic of Congo: The search for a Regional conflict transformation mechanism premised on collective security and the African ethical concept of Ubuntu (Unpublished doctoral dissertation). Retrieved from https://researchspace.ukzn.ac.za/bitstream/ handle/10413/14852/Rugeje_Engelbert_Abel_2016.pdf?sequence=1\&isAllowed=y

Rugeje, E. A., \& Maeresera, S. (2016). The United Nations force intervention brigade: Wither the SADC/ICGLR synchronised peace support efforts in the Eastern Democratic Republic of Congo recurring conflict? Journal of International Studies $12,65-79$.

Zambara, W. (2013, January 4). SADC's peace plan faces challenges. mail and guardian. Retrieved from http://mg.co.za/article/2013-01-04-00-sadcs-peace-plan-faceschallenges. 